\title{
IMPLEMENTASI CONTENT BASED LEARNING DALAM PENGAJARAN DRAMA
}

\author{
Noni Marlianingsih \\ Universitas Indraprasta PGRI \\ Marleeanee.nm@gmail.com \\ Tita Puspitasari \\ Universitas Indraprasta PGRI \\ Tita1984ps@gmail.com
}

\begin{abstract}
ABSTRAK
Pengajaran Drama sebagai mata kuliah teori dihadapkan pada banyak kendala. Pengunaan teknik ceramah dan teknik presentasi murni cenderung membuat mahasiswa pasif dan tidak dapat memahami materi dengan baik. Sementara itu, pengajaran mata kuliah ini tidak hanya diarahkan pada pemahaman saja, namun diharapkan agar mahasiswa menjadi lebih kreatif dan inovatif. Tujuan penulisan artikel iniadalah untuk berbagi pengalaman tentang keefektifan penggunaan content based learning dalam pengajaran drama. Penulis menggunakan metode pengajaran Content Based Learning dalam kelas drama, jurusan pendidikan Bahasa Inggris, Universitas Indraprasta PGRI. Mahasiswa yang diajar berada di tahun ke dua atau semester empat. Kelas yang diajar sebanyak dua kelas, masing-masing kelas berjumlah 30 orang. Hasil dari penerapan metode pengajaran ini, mahasiswa dapat menganalisa dan membandingkan unsur-unsur drama yang ada di teks aslinya dan versi film, sehingga mereka dapat mementaskannya di kemudian hari. Manfaat lain yang diperoleh dari penggunaan metode ini yaitu mahasiswa dan dosen menjadi lebih aktif saling berkomunikasi dan mahasiswa terbiasa bekerjasama dalam kelompoknya.
\end{abstract}

Kata Kunci: content based learning, drama.

\section{ABSTRACT}

Teaching Drama as a theory course is confronted with many obstacles. The using of lecture and pure presentation techniques tend to make passive students and they cannot understand the material well. Meanwhile, teaching drama is not only in order to understand the text, but it is expected that students become more creative and innovative. The purpose of this article is to share experiences about the effectiveness uses content based learning in teaching drama. The methodology was applied in English education program, University Indraprasta PGRI. Students who are taught are in the second year or fourth semester. Consists of two classes, each class of 30 students. The result is expected that students enable to analyze and compare the existing drama elements in the original text and film version so they can perform it in the future. Other benefits derived from the use of this method are students and lecturers become more active communicate with each other and students are accustomed to work together in groups.

Key Words: content based learning, drama 


\section{PENDAHULUAN}

Para tokoh pendidikan menganggap perlu untuk mempelajari drama khususnya bagi mahasiswa, karena dengan mempelajarinya dapat membantu mahasiswa untuk lebih peka kepada lingkungannya dan dapat membentuk karakter dari pribadi mereka masing-masing menjadi lebih dewasa. Drama merupakan sebuah wadah ungkapan seni melalui cerita dan biasanya harus dimainkan dalam pentas. Berbagai macam karakter dapat kita temui disini, diantaranya karakter-karakter yang merupakan cerminan dari sifat dasar manusia seperti protagonis, antagonis dan netral.

Mendapatkan tugas untuk mengajar mata kuliah drama tidak lah mudah seperti yang dibayangkan. Sebagai pengajar dituntut untuk memiliki strategi dalam mengajar, agar aktifitas di dalam kelas tidak monoton dan membosankan mahasiswa. Aktifitas di kelas tidak bisa hanya mengandalkan membaca atau membahas buku-buku teori dan karya-karya drama saja. Namun perlu pengajaran yang bertujuan untuk mengasah kreatifitas mahasiswa.

Pembaharuan dalam teknik mengajar diperlukan di dalam mata kuliah drama, sehingga mahasiswa tertarik dan memahami unsur-unsur di dalam drama seperti tema, alur, tokoh dan penokohan, gaya bahasa, pesan atau nilai-nilai (moral, sosial, agama, budaya) yang ingin disampaikan oleh si penulis pada karya dramanya. Selain itu tantangan yang harus dihadapi oleh seorang pengajar yaitu menanamkan rasa percaya diri yang besar kepada mahasiswanya agar bisa membuat sebuah pertunjukkan layaknya seorang seniman professional, dimana tidak hanya bisa memahami cerita dari sebuah karya drama terkenal. Namun juga bisa mementaskannya, dimulai dengan belajar membuat skenario cerita yang dibuat lebih singkat dari durasi asli ceritanya yaitu lebih dari dua jam. Setelah itu dapat mensutradarai atau memerankan sebuah karakter atau berperan karakter ganda. Sehingga penonton yang menyaksikannya menjadi terkesima dan terhanyut dengan drama yang dipentaskan, selain itu penonton dapat mengambil hikmah dari pementasan itu. Berdasarkan problematika dan liku-liku dalam mengajar drama yang telah dijelaskan sebelumya. Penulis ingin membagi pengalaman mengajar drama menggunakan content based learning pada artikel ini.

\section{Rumusan Masalah}

Berdasarkan uraian dalam latar belakang, masalah utama dalam tulisan ini adalah" Bagaimanakah penggunaan content based learning dalam pengajaran drama?"

\section{Tujuan Penulisan}

Tujuan penulisan artikel ini adalah untuk berbagi pengalaman tentang keefektifan penggunaan content based learning dalam pengajaran drama.

\section{METODOLOGI}

Penulis menggunakan metode pengajaran Content Based Learning dalam kelas drama, jurusan pendidikan Bahasa Inggris, Universitas Indraprasta PGRI. Mahasiswa yang diajar berada di tahun ke dua atau semester empat. Kelas yang diajar sebanyak dua kelas, masing-masing kelas berjumlah 30 orang. 


\section{Tinjauan Pustaka}

\section{Drama}

Drama adalah bentuk sastra yang dapat merangsang gairah dan mengasyikkan para pemain dan penonton sehingga sangat digemari masyarakat. Bentuk ini didukung oleh tradisi sejak jaman dulu yang melekat erat pada budaya masyarakat setempat. Di samping mudah disesuaikan untuk dimainkan dan dinikmati masyarakat segala umur, drama sangat tinggi nilai pendidikannya (Rahmanto, 1988: 82). Karena drama merupakan peragaan tingkah laku manusia yang mendasar, drama baru dapat disusun dan dipentaskan dengan berhasil jika diikuti pengamatan yang diteliti baik oleh penulis maupun para pemainnya. Tokoh-tokoh pendidikan melihat bentuk sastra ini sebagai suatu wadah bagi generasi muda dalam menuju kedewasaannya dengan melakukan berbagai macam peran yang perlu dipahami benar. Dengan menghayati berbagai macam peran, para pemuda akan memiliki wawasan yang lebih luas tentang hidup dan kehidupan yang dihadapinya.

\section{Pengajaran Drama}

J.S. Bruner (Rahmanto, 1988: 83) dalam bukunya berjudul Towards a Theory of Instruction mengungkapkan bahwa

Drama, novel, sejarah pada umumya...disusun berdasarkan lawan asas pilihan manusia yang merupakan pemecahan atas satu pilihan antara dua kemungkinan yang dihadapinya. Karya-karya itu menurut artinya yang terdalam, sebenarnya merupakan 'pelajaran' tentang sebab-akibat pilihan manusia. Karena isinya yang menarik dan dekatnya pada kehidupan, karya-karya itu dapat dijadikan ungkapan untuk menyoroti dilema budaya, termasuk aspirasinya, konflik dan bahkan terror-terornya...sampai pada taraf tertentu kita telah mengintelektualkan dan mendisiplinkan fakta-fakta sejarah maupun mitos. Maka dalam menyusun rencana pelajaran hendaknya kita memikirkan cara yang dapat memberikan wawasan tentang sifat dan keadaan manusia yang sebenarnya satu sama lain berbeda. Dramatisasi merupakan suatu cara yang baik untuk menyampaikan hal itu. Cara ini perlu lebih digarap dengan serius karena dapat menimbulkan gerak hati yang kuat untuk mengungkap keadaan manusia yang sebenarnya, sehingga 'pelajaran' seakan merupakan drama tentang kehidupan manusia.

Tujuan utama dalam mempelajari drama adalah untuk memahami bagaimana suatu tokoh harus diperankan dengan sebaik-baiknya dalam suatu pementasan. Untuk mempelajari pementasan ini memang tidak selalu mudah, terutama bagi mahasiswa yang sama sekali belum mengenal pelik-pelik keadaan suatu pentas drama. Untuk itu, seorang dosen (pelatih) drama bertanggung jawab untuk memperkenalkan para mahasiswanya pada kondisi pementasan drama. Dalam beberapa hal, lingkungan mahasiswa sehari-hari (misalnya: TV, sandiwara, film dsb.) dapat dimanfaatkan untuk membantu menyampaikan pengalaman pementasan yang nyata. Namun, dalam beberapa hal lain, dosen hendaknya dapat memberikan gambaran tentang proses dramatisasi yang lebih lengkap daripada pengetahuan yang dimiliki mahasiswanya berdasarkan pengalaman hidupnya sehari-hari.

Mempelajari naskah drama di satu pihak dan pentas drama di pihak lain, merupakan dua aktivitas yang jauh berbeda. Namun, demi kejelasan, hendaknya perbedaan aktivitas tersebut ditekan seminimal mungkin. Pertama, perlu diingat bahwa drama, di mana pun selalu mengandung sejumlah bentuk dan gaya yang berbeda satu sama lain. Kedua, perlu dipahami bahwa bentuk dan gaya itu 
mempunyai tujuan yang tidak sama. Jika bentuk dan gaya ini dicampuradukkan sedemikian rupa, maka akan sangat mengecewakan. Misalnya, apabila terjadi suatu kesalahan besar apabila pementasan tragedi, lantaran keliru menafsirkannya, maka akan ditanggapi para penonton justru sebagai bahan tertawaan; sebaliknya bentuk komedi malahan ditanggapi penonton dengan tegang dan serius.

Diperlukan proses belajar yang cukup lama bagi para mahasiswa untuk dapat memahami tiap-tiap perbedaan bentuk dan gaya dalam drama tersebut. Perbedaan ini biasanya dapat dikenali lewat istilah kunci seperti misalnya tragedi (tentang kesedihan dan kemalangan) dan komedi (tentang lelucon dan tingkah laku konyol). Drama komedi sering dibagi menjadi melodrama dan farce (drama olok-olok) yang masing-masing memiliki ciri-ciri sendiri meskipun ada kesamaannya. Jenis drama macam ini sering masih dibedakan pula ke dalam drama-drama riil dan drama-drama simbolik. Untuk penyajian drama yang realis ini perlu disiapkan situasi yang mendekati kenyataan sebenarnya dalam pementasannya, misalnya dalam pemakaian bahasanya, kostum, tata panggung dan sebagainya. Sedangkan pada drama simbolik, dalam pementasannya tidak perlu mewakili apa yang sebenarnya terjadi dalam realita. Bahasa dalam drama simbolik ini misalnya, dapat dibuat puitis, dibumbui dengan musik, tarian, koor dan bahkan sering cukup dengan panggung kosong tanpa hiasan yang melukiskan realita.

Di samping itu, dalam mempelajari drama mahasiswa juga perlu diperkenalkan pada berbagai variasi pementasan atau aturan-aturan pementasan tertentu yang selama ini masih berlaku di berbagai tempat. Kemungkinankemungkinan variasi panggung yang umum, misalnya: panggung sandiwara yunani, panggung Inggris abad pertengahan, panggung Elizabetahan, procenium Theatre dan panggung-panggung modern lain yang dilengkapi dengan video, TV dan film. Sekali lagi, sehubungan dengan variasi panggung ini gaya pementasan dapat dibedakan dalam dua kategori. Pertama, panggung ketat yakni permainan disajikan berupa'pertunjukkan penuh' di atas panggung. Penonton dapat mengamati permainan secara keseluruhan dari luar daerah panggung. Kedua, panggung bebas yang memanfaatkan seluruh gedung sebagai arena pertunjukkan. Dalam hal ini permainan tidak selalu terjadi di atas panggung.

\section{Content Based Learning}

Dalam pengajaran bahasa dikenal suatu pendekatan yaitu, Content based learning (CBL) atau Pengajaran Berbasis Konten ini sangat popular dalam dua puluh tahun terakhir, khususnya di Amerika dan Kanada karena keefektifan dalam program imersi.

Pengajaran Berbasis Konten (Content Based Learning) didefinisikan Crandall sebagai: "sebuah pendekatan untuk pengajaran bahasa yang mengintegrasikan penyajian topik atau tugas dari materi pelajaran di kelas, (misalnya, matematika, ilmu sosial) dalam konteks pengajaran bahasa kedua atau asing" (Crandall dan Kauffman, 1987: 9). Pengajaran berbasis konten mengacu kepada pendekatan untuk pengajaran bahasa kedua di mana pengajaran ditekankan pada konten atau informasi yang akan diperoleh mahasiswa. Pengajaran berbasis konten merupakan pengajaran yang dirancang sesuai dengan topic yang dipilih dan pengajarannya juga berdasarkan pada topik-topik tersebut. Krahnke mengemukakan bahwa "It is the teaching of content or information in the language being learn with little or no direct or explicit effort to teach the language itself separates the content being taught" (Krahnke, 1987: 26).

Jadi, menurut Krahnke, Content based learning ( $C B L)$ merupakan pemberian konten atau informasi melalui bahasa yang sedang dipelajari sehingga tidak terlihat 
secara langsung bahwa kegiatan tersebut merupakan kegiatan belajar bahasa. Selain itu, dalam menggunakan pendekatan ini tidak ada pemisahan tertentu antara pengajaran bahasa dengan pengajaran kontennya, jadi pengajaran bahasa dan pengajaran konten menjadi terpadu.

Stryker dan Level mendefinisikan Content based learning (CBL) sebagai sebuah pendekatan pengajaran di mana "Language proficiency is achieved by shifting the focus of the course from learning language per setting to the learning of subject matter" (Stryker, et, al, 1999: 270) Artinya kemampuan berbahasa didapatkan sejalan dengan proses pembelajaran topif atau subjek tertentu.

Dari beberapa uraian di atas, dapat disimpulkan bahwa pengajaran berbasis konten adalah sebuah pendekatan yang mengkolaborasikan antara pengajaran konten dengan pengajaran bahasa. Dalam pelaksanaanya, pengajaran keterampilan berbahasa dengan pengajaran konten itu sendiri tidak terpisah sehingga secara tidak sadar yang dipelajari lebih cenderung kepada penggunaan keterampilan bahasa sasaran, bukan kepada ilmu kebahasaan itu sendiri.

Selain alasan yang dikemukakan di atas, Richards dan Rodgers (2005: 207) mengemukakan pengajaran bahasa berbasis konten didasarkan pada dua prinsip utama:

1) Orang belajar bahasa kedua lebih berhasil ketika mereka menggunakan bahasa sebagai sasaran untuk memperoleh informasi, bukan sebagai tujuan itu sendiri. Dalam pengajaran berbasis konten, bahasa bukan subjek yang harus dipelajari, tetapi sebagai sasaran untuk mempelajari subjek (konten)

2) Pengajaran berbasis konten lebih mencerminkan kebutuhan peserta didik untuk belajar bahasa kedua. Hal ini mencerminkan kebutuhan peserta didik. Dengan demikian, pilihan konten harus mempertimbangkan tingkat kemampuan peserta didik saat itu, tujuan akademik, minat, dan kebutuhan. Prinsip ini mencerminkan fakta bahwa banyak program dari CBI berfungsi untuk mempersiapkan mahasiswa ESL untuk belajar secara akademik. Oleh karena itu, kebutuhan untuk dapat mengakses konten pembelajaran akademik dan pengajaran secepat mungkin, serta realisasi proses belajar mengajar adalah prioritas utama.

Dari beberapa pemikiran tentang alasan pengunaan pengajaran berbasis konten tersebut dapat diasumsikan bahwa pengajaran berbasis konten dapat diterapkan untuk meningkatkan pengetahuan pelajar bersamaan dengan peningkatan keterampilan berbahasa dan juga untuk meningkatkan motivasi dalam menguasai bahasa target.

\section{Desain: Tujuan, Silabus, Kegiatan Pembelajaran, Peran Serta Peserta Didik, Dosen dan Materi Ajar}

Tujuan dari pengajaran berbasis konten mengikuti theme based intensive Language Course (ILR) di Universita Berlin. Keempat ciri-ciri dari tujuan pengajaran berbasis konten adalah linguistik, strategi, dan kebudayaan. Adapun tujuan secara khusus adalah sebagai berikut.

a) Untuk mengaktifkan dan mengembangkan keterampilan berbahasa Inggris yang telah ada,

b) Untuk memperoleh keterampilan pembelajaran dan strategi yang dapat diaplikasikan dalam pengembangan bahasa ke depannya.

c) Untuk mengembangkan keterampilan akademik umum yang dapat diaplikasikan pada seluruh pembelajaran di Universitas.

d) Untuk memperluas pemahaman mahasiswa tentang orang yang berbahasa Inggris (Brinton, 1989: 32).

Silabus 
Pada kebanyakan pengajaran berbasis konten, silabus dimunculkan dari wilayah konten, dan bervariasi. Biasanya pengajaran berbasis konten mengikuti theme based model dimana konten dan urutan pengajaran yang dipilih disesuaikan dengan tujuan pembelajaran bahasa. Theme based model menggunakan jenis silabus yang disebut dengan silabus topikal, organisasi yang dibangun sekitar topik dan subtopik yang spesifik.

\section{Jenis Kegiatan Belajar Mengajar}

Ada beberapa gambaran dari jenis kegiatan pada pengajaran berbasis konten, Stoller mengklarifikasikan menurut fokus pembelajaran. Adapun kategori yang diusulkan adalah sbagai berikut.

1. Peningkatan keterampilan berbahasa;

2. Pengembangan kosakata;

3. Organisasi wacana;

4. Interaksi komunikatif;

5. Keterampilan belajar;

6. Sintesis konten, material, dan tata bahasa.

\section{Peran Pembelajar}

Stryker dan Lever mengungkapkan bahwa "one goal of CBI is for learner to become autonomous so that they come to understand their own learning process and ...take charge of their learning from the very start” (Stryker, 1999: 39).

Bahwa salah satu tujuan dari pengajaran berbasis konten adalah bagi peserta didik untuk menjadi berani dalam memahami proses belajar mereka sendiri dan...memulai pembelajaran mereka dari awal. Selain itu, mahasiswa akan saling mendukung satu sama lainnya dalam model pembelajaran kolaboratif ini. CBI merupakan "learning by doing" model, dimana mahasiswa berperan aktif dalam pembelajaran.

\section{Peran Dosen}

Stryker dan Lever mengemukakan: "instructors must be more than just good language teachers. They must be knowledgeable in the subject matter and able to elicit that knowledge from their student" ((Stryker, 1999: 44)

Maksudnya adalah instruktur harus lebih dari sekedar dosen bahasa yang baik. Mereka harus berpengetahuan dalam materi pelajaran dan mampu juga memperoleh pengetahuan dari murid-muridnya. Lebih rincinya lagi, dosen harus tetap mudah dipahami terutama dalam melakukan perencanaan dan presentasi pembelajaran. Dosen juga bertanggung jawab dalam memilih dan menggunakan materi yang otentik, dan juga mampu menciptakan kelas yang benar-benar berpusat pada peserta didik.

Stryker dan Leaver (1999: 44) menyarankan beberapa keterampilan penting dalam pengajaran bahasa CBI seperti berikut.

a) Model-model format pengajaran di dalam kelas;

b) Menggunakan kelompok kerja dan tim untuk membangun teknik;

c) Menggunakan model pembelajaran jigsaw;

d) Menetapkan dasar pengetahuan dan kebutuhan keterampilan mahasiswa;

e) Membantu mahasiswa memgembangkan strategi lain;

f) Menggunakan pendekatan proses dalam menulis;

g) Menggunakan teknik perbaikan kesalahan yang tepat;

h) Mengembangkan dan mempertahankan mahasiswa yang mempunyai prestasi. 


\section{Peran Materi/Bahan Ajar}

Materi atau bahan ajar yang memfasilitasi pembelajaran bahasa adalah bahwa bahan yang digunakan pada materi pelajaran atau konten yang dipelajari. Materi yang digunakan adalah materi yang asli. Keaslian menyiratkan bahwa materi atau bahan ajar dalam pembelajaran sama seperti yang digunakan oleh penutur asli. Banyak ahli yang menyarankan penggunaan realitas seperti buku paduan wisata, jurnal teknis, jadwal kereta api, iklan surat kabar, radio, dan siaran TV.

\section{Prosedur Pelaksanaan Pengajaran Berbasis Konten}

Seperti diketahui bahwa model pengajaran bahasa berbasis konten mengacu pada pendekatan daripada metode, tidak ada teknik atau kegiatan khusus yang terkait dengannya. Pada tingkat prosedur, bahan ajar dan kegiatan dipilih sesuai dengan prinsipprinsip dari CBL tersebut. Stryker dan Leaver (1997: 198-199) menggambarkan model khas prosedur pelajaran berbasis konten. Salah satu contoh adalah pelajaran bahasa Spanyol yang diambil pada tinjaun Film El Norte.

Persiapan awal: bahan referensi baca mahasiswa mengenai undang-undang imigrasi AS serta salah satu kutipan El Laberinto de La Soledad karya Octavio Paz.

1) Linguistic analysis: discussion of grammar and vocabulary based on students' analysis of oral presentations done the day before.

2) Preparation for film: activities previewing vocabulary in the film, including a vocabulary worksheet.

3) Viewing a segment of movie.

4) Discussion of the film: The teacher leads a discussion of the film.

5) Discussion of the reading.

6) Videotaped interview: students see a short interview in which immigration matters are discussed.

7) Discussion: a discussion of immigration reform.

8) Preparation of articles: Students are given time to read related articles and prepare a class presentation.

9) Presentation of articles: Student makes presentations, which may be taped so that they can later listen for self-correction.

10) Wrap-up discussion.

\section{PEMBAHASAN}

\section{Implementasi Kolaborasi Content Based Learning dalam Pengajaran Drama}

Berdasarkan dari tujuan pembelajaran menggunakan content based learning yaitu mahasiswa dapat memahami teks drama dalam bahasa inggris sesuai dengan topik dan bentuknya seperti tragedi, komedi, tragekomedi, opera, melodrama, sejarah, misteri, lelucon, laga, operet. Peningkatan dan pemerolehan kosa kata dalam bahasa Inggris didapat dari membaca teks-teks drama, setelah mereka mahir dalam memahami content dari teks drama tersebut, maka mereka dapat mengaplikasikannya terutama pada saat pementasan drama. Dimulai dengan menulis ulang kembali skenario drama, menggunakan kata-kata bahasa inggris yang lebih mudah dipahami dan dihafal. Selain itu, durasi pementasannya lebih singkat dari teks aslinya.

Penerapan dalam pengajaran drama dengan menggunakan content based learning, yaitu menggunakan teks drama dari penyair atau pujangga Inggris ternama seperti 
William Shakespear. Selain itu mahasiswa dapat memahami secara khusus tentang terminologi dan konsep dari drama, diantaranya membuat tugas laporan untuk mengasah keterampilan menulis berdasarkan hasil analisa atau mengkaji karya drama Inggris yang masih original bukan saduran, atau membuat dialog pementasan drama berdasarkan naskah aslinya, seperti yang telah dijelaskan sebelumnya, yaitu dengan menuangkannya dalam bentuk tulisan dan lisan sesuai kaidah tata bahasa Inggris. Pelaksanaan kegiatan belajar mengajar dengan menggunakan metode content based sebagai berikut.

Memahami Content Teks Drama: pembahasan content berupa membaca karyakarya drama Inggris dari William shakespear, teks dan bahasanya masih sesuai dengan karya aslinya. Adapun judul drama yang dibaca yaitu Romeo dan Juliet, The Merchant of Venice, Othello, dan Hamlet. Pertama-tama setiap mahasiswa diberi teks drama tersebut agar dapat dibaca dan dipelajari sendiri-sendiri. Teks-teks drama yang dibagikan hendaknya disertai pertanyaan-pertanyaan sebagai bahan diskusi dalam usaha memahami dan menghayati drama tersebut.

Dibawah ini diberikan contoh pertanyaan-pertanyaan yang dapat didiskusikan setelah mahasiswa membaca teks drama berjudul penggali Romeo dan Juliet

(a) Mengapa keluarga Romeo dan Juliet saling bermusuhan?

Apa alasan mereka masing-masing?

(b) Kejadian apa yang mempertemukan Romeo dan Juliet?

(c) Apa yang terjadi setelah pertemuan antara Romeo dan Juliet?

(d) Mengapa Romeo tetap nekad menikahi Juliet?

(e) Apa yang direncanakan oleh Romeo dan Juliet?

(f) Apakah keluarga Romeo dan Juliet mau menyetujui hubungan mereka berdua?

Setelah mendiskusikan fakta lewat pertanyaan-pertanyaan itu, mahasiswa lalu diajak memasuki proses pementasan. Proses itu dimulai dengan pembacaan bersama di kelas kemudian didiskusikan bersama untuk menelusuri fakta-fakta lebih lanjut. Agar pembacaan bersama ini dapat berjalan dengan lancar, dosen hendaknya memilih mahasiswa yang dapat membaca dengan baik sebagai model, kalau perlu disesuaikan dengan peran yang mereka bawakan. Disamping itu, dosen juga perlu memilih seorang sutradara (atau dia sendiri) yang tidak hanya memahami alur ceritera, tapi juga dapat mebaca arah penampilan panggung dan bila perlu dapat menggambarkan situasi serta memberi komentar secara spontan dan jelas.

Pada pembacaan bersama yang pertama mungkin masih akan banyak terjadi kesalahan, misalnya: salah tutur, salah tekanan dan mungkin salah pengucapan kalimat. Demi kelancaran, pembacaan hendaknya tidak terhenti karena pembetulan kesalahankesalahan semacam itu. Akan tetapi, dosen hendaknya dengan diam-diam memperhatikannya untuk kemudian diperbaiki pada langkah selanjutnya. Hal itu dilakukan jika kesalahan yang sama muncul lagi. Banyak kesalahan semacam itu yang hilang dengan sendirinya setelah dosen memberikan contoh yang benar pada diskusi selanjutnya.

\section{Teks Drama dan Menonton Film}

Setelah diadakan sekali atau dua kali pembacaan seperti yang diungkapkan di atas, mahasiswa di kelas akan menjadi lebih siap mendiskusikan aspek-aspek drama secara lebih terinci. Diskusi ini hendaknya dilaksanakan berdasarkan pertanyaanpertanyaan tentang faktor-faktor yang mendalam untuk memperbaiki wawasan si mahasiswa tentang makna dan implikasi berbagai pembicaraan dari teks yang tengah dipelajari. Disamping itu, mahasiswa juga diharapkan memperdalam pemahamannya tentang pemikiran-pemikiran yang melatarbelakangi cerita serta kesesuaian antara kata- 
kata dan gerak yang akan ditampilkan. ("Sesuaikan gerak dengan kata-kata dan kata-kata dengan gerak"). Dalam diskusi ini juga perlu dibahas kesesuaian antar tokoh satu dengan yang lain dan pencarian tema-tema umum. Agar diskusi dapat lebih terarah, setiap tahap pembicaraan hendaklah selalu dikontrol dan disesuaikan berdasarkan teks drama. Selanjutnya dosen akan mempersiapkan film yang akan ditonton dengan judul Romeo dan Juliet, The Merchant of Venice, Othello, dan Hamlet. Lalu film ditayangkan hanya sekilas atau synopsis filmnya saja. Kemudian dosen memberikan kebebasan kepada mahasiswa untuk memilih judul film yang mereka sukai dan jalan ceritanya sudah mereka pahami.

\section{Analisis Film}

Pada tahapan ini dosen menyediakan film yang akan di tonton oleh mahasiswa, dikarenakan oleh keterbatasan waktu dan tempat. Sehingga menonton judul film yang sudah disepakati bersama, diadakan di rumah masing-masing mahasiswa. Pada tahapan ini, mahasiswa tidak hanya sekedar menonton film namun juga mencatat dan menganalisa film yang ditontonnya. Adapun hal-hal yang perlu dianalisa berupa:

a. menganalisa setting, tema, karakter dan plot, style dan hal yang menonjol dari film drama dan dibandingkan dengan teks drama.

b. menjelaskan keutamaan dari pemain atau karakter utama di film dan teks drama.

c. menjelaskan motivasi dari perilaku para pemain di dalam film tersebut dan teks drama.

d. membandingkan alur cerita atau susunan dari teks drama dengan filmnya.

e. menganalisis penggunaan bahasa retorika atau majas yang digunakan oleh para pemain dan yang ada dalam teks drama

\section{Membahas Film}

Diskusi lebih lanjut perlu dilaksanakan di kelas untuk memperdalam pemahaman isi teks dan film. Pembahasan merupakan tindak lanjut dari hasil analisa mereka berdasarkan film yang mereka telah tonton dan teks drama yang sudah mereka baca. Disamping pembahasan yang mendalam tentang isi teks dan film, diskusi hendaknya disertai dengan peragaan praktis adegan-adegan tertentu yang perlu mendapatkan perhatian khusus.Dalam pelajaran drama, ada berbagai macam pengukuhan yang dapat dilakukan, misalnya: melaporkan pementasan drama, menuliskan dialog, membuat adegan. Sedangkan maksud pemeragaan dalam pelajaran drama ini, sebenarnya lebih mengarah pada mendorong para mahasiswa agar mampu menerjemahkan teks drama dengan baik, sehingga mereka siap untuk berakting. Ini sangat penting, sebab dalam pementasan drama dibutuhkan perhatian penuh terhadap unsur gerak dan mimik wajah untuk dapat menjiwai peran. Ada banyak faktor yang menentukan keberhasilan suatu pementasan drama. Dua faktor utama yang sangat menetukan adalah: (a) waktu yang tersedia; (b) pengalaman dan ketrampilan praktis yang dimiliki oleh mahasiswa dalam bermain drama.

\section{Praktik Percobaan}

Setelah diskusi berjalan lancar, biasanya mahasiswa ingin segera mempraktekkan apa yang telah mereka bahas. Dosen dapat memanfaatkan nafsu bermain ini dengan membawa mereka ke aula atau di halaman kampus yang cukup luas agar mereka dapat leluasa berlatih gerak dan dialog. Sebagai langkah permulaan, perlu dipraktekkan beberapa adegan yang dramatis, misalnya: Romeo dan Juliet tidak sengaja bertemu di sebuah pesta, lalu mereka jatuh cinta, kemudian mereka berniat melarikan diri bersama untuk menikah, dikarenakan keluarga mereka yang saling bermusuhan. Untuk dapat melibatkan semua mahasiswa dalam latihan ini, kelas dapat dibagi ke dalam kelompok 
yang beranggotakan 8 atau 10 orang mahasiswa. Setiap kelompok diberi tugas untuk mempelajari adegan tertentu, kemudian memerankannya dengan versi mereka sendiri untuk diamati oleh teman-teman sekelas yang lainnya. Cara ini cocok untuk menumbuhkan pemikiran baru, saran-saran dan perbaikan pada praktek pementasan selanjutnya.

\title{
Latihan Mengucapkan Dialog
}

Agar pementasan nanti dapat berhasil baik, setelah latihan gerak, dosen hendaknya mengajak calon-calon pemain untuk kembali meneliti teks drama dan menyiapkannya sebagai bahan hafalan. Sebelum tiap-tiap pemain mencoba menghafalkan perannya, dosen hendaknya sudah memperoleh keyakinan bahwa setiap pemain telah memahami cara penyampaian setiap kata, frase, maupun kalimat-kalimat yang harus diucapkan. Untuk itu, sebelumnya mereka harus diajak untuk memperhatikan: lafal, lagu, tekanan, jeda, tempo, ekspresi wajah dan suasana keheningan yang sangat perlu dalam pementasan yang ada kalanya justru dapat menimbulkan suasana yang sangat dramatis.

\begin{abstract}
Akting
Membawakan dan menghidupkan dialog teks memang sangat penting, tetapi yang tidak kalah pentingnya adalah mengolah gerak dan ekspresi wajah para pemain. Seorang sutradara dalam hal ini seorang dosen drama, harus mempunyai gambaran yang jelas tentang bagaimana akting para pemain di pentas, seperti misalnya: kapan seorang pemain harus muncul, bagaimana posisinya, kapan harus mengubah posisi, gerakan apa yang harus dilakukannya agar dapat menimbulkan efek dramatis dan sebagainya. Saat yang tepat untuk memberikan gambaran tentang tingkah dan gerak para pemain di pentas ini adalah setelah para pemain hafal teks. Mereka dapat membuat catatan di mana mereka akan masuk panggung, di mana harus berdiri, bagaimana dan kapan harus bergerak, dan sebagainya sesuai dengan teks drama yang akan dimainkan.
\end{abstract}

\section{Pementasan}

Apabila pentas drama ini dimaksudkan untuk umum dan dimainkan di panggung dengan penonton yang terdiri dari Rektor, Dekan, Kaprodi dan mahasiswa. Para audiens dan dosen drama harus bertindak sebagai produser dan sutradara yang baik. Artinya dosen harus memilih pemain dengan selektif, melatih secara khusus, dan membagi tugas untuk persiapan pementasan seperti: siapa yang bertanggung jawab untuk perlengkapan panggung, tata rias, tata musik, tata lampu, pembisik, properti, dan sebagainya.

Akan tetapi apabila pentas drama ini hanya akan disajikan dalam rangka loka karya drama atau hanya untuk mata kuliah drama, tugas dosen akan jauh lebih ringan. Dalam persiapan pementasan tidak perlu disediakan seluruh perlengkapan panggung seperti tersebut di atas. Jika terpaksa ada beberapa orang pemain yang diijinkan membawa teks drama, dan sekali boleh menengok teks jika ia lupa pada baris-baris yang harus dibawakannya. Tetapi dalam persiapan pementasan semacam ini, langkah-langkah yang harus ditempuh para mahasiswa untuk menghidupkan teks drama perlu diberikan secara rinci pula. Ini adalah termasuk kegiatan apresiasi drama yang harus dilakukan para siswa.

\section{Simpulan}

Dari uraian teori dan pelaksanaan pengajaran drama dengan menerapkan content based learning dapat disimpulkan beberapa hal berikut.

1) Mahasiswa dapat menganalisissetting, tema, karakter dan plot, style dan hal yang menonjol dari film drama dan dibandingkan dengan teks drama.

2) Mahasiswa dapat menjelaskan keutamaan dari pemain atau karakter utama dan karakter lainnya di film dan juga teks drama. 
3) Mahasiswa dapat menjelaskan motivasi dari perilaku para pemain di dalam film tersebut dan teks drama.

4) Mahasiswa dapat membandingkan alur cerita atau susunan dari teks drama dengan filmnya.

5) Mahasiswa dapat menganalisa penggunaan bahasa retorika atau majas yang digunakan oleh para pemain dan yang ada dalam teks drama

\section{Saran}

Mencermati kelebihan yang dapat diambil dari penerapan content based learning dalam pengajaran mata kuliah drama. Diharapkan dapat membantu kelancaran dan proses pemahaman mahasiswa terhadap teks drama Inggris yang sebenarnya sulit dipahami dikarenakan bahasa yang digunakan di dalam teks tersebut masih menggunakan bahasa Inggris lama dan selain itu juga membantu mahasiswa mempermudah menganalisa film yang diangkat dari teks drama asli yang nota bene menggunakan dialog bahasa Inggris yang berat dan panjang, selain itu juga durasi film yang cukup menyita waktu karena memakan waktu rata-rata untuk satu film bisa tiga jam atau lebih. Karena hal tersebut membutuhkan ketahanan, konsentrasi, dan juga strategi belajar yang baik. 


\section{DAFTAR PUSTAKA}

Brinton, et, al. 1989. Content Based Second Language Instruction. United State of Amerika: Heinle\&Heinle.

Crandall dan Kauffman Dorrit. 1987. EST through Content Area Instruction; Mathematic, Science, Social Studied. Eaglewood Cliffs, NJ: Prentice Hall Regent.

K. Krahnke. 1987. Approach to Syllabus Design for Foreign Language Teaching. New York: Prentice Hall.

Jack C. Richards and T.S Rodgers. 2005. Approach and Methods in Language Teaching. Cambridge: Cambridge University Press.

Rahmanto, B. 1988. Metode Pengajaran Sastra. Yogyakarta: Kanisius.

Stryker, et, al. 1999. Content based learning in Foreign Language Education. Washington D.C. University Press. 